\title{
REFLECTION
}

\section{One Cold Autumn Day}

Peter de Schweinitz, MD, MSPH ${ }^{1,2}$

${ }^{1}$ Chief Andrew Isaac Health Center, Fairbanks, Alaska

${ }^{2}$ Department of Family and Preventive Medicine at the University of Utah School of Medicine, Salt Lake City, Utah
Annals Journal Club selection see inside back cover or http://www.ann fammed.org/AJC/.

Conflicts of interest: author reports none.

\section{CORRESPONDING AUTHOR}

Peter de Schweinitz, MD, MSPH

Chief Andrew Isaac Health Center 1717 W. Cowles St.

Fairbanks AK 99701

p_de_schweinitz@hotmail.com

\begin{abstract}
Behavioral change is at the heart of effective primary care, but when patients don't change, how do we account for our days? In this personal essay, I relate an encounter with a patient who wants to quit smoking, lose weight, and control her diabetes. I am discouraged when she deflects my recommendations, but a colleague's comment encourages a deeper inquiry. Knowing the patient's story and deepening the conversation, however, do not guarantee change. The experience reminds me why patience, humility, and faith are core values of the primary care physician.
\end{abstract}

Ann Fam Med 2015;13:279-281. doi: 10.1370/afm.1781.

S ometimes I feel angry with the patient. She's a 44-year old, morbidly obese, diabetic who flies in from the Alaskan bush to be seen for "medication renewal" and "wound care" at the tribal urgent care. After a brief review, I level with her: "You know if you lost weight, you could probably get off all 10 of these medicines." I don't say it meanly, though, because frustration is not all I feel. I care. But sometimes, when my embers have grown dim, the caring looks a bit more like cold, biomedical efficiency.

"What kinds of foods do you eat?" I ask.

"Just regular food," she replies.

"Uh huh. Like what?"

The more I learn about her body and behaviors, the more "to the point" I become. It's not only impatience that drives me. It's fear. Images of cracking, yellow plaque, a fatty hardening of the arteries, sharpen my pursuit.

"Do you drink?"

"No."

"You smoke, though."

"Yeah."

"Have you tried to quit?"

"Yeah. I've tried everything."

"What have you tried?"

"The patches, the gum..."

"Have you tried pills, like Wellbutrin or Zyban?"

"I tried that. They made me really on edge."

"How about Chantix?"

"I tried that twice, but they told me I couldn't get any more."

"Yeah, they won't give you that for more than 3 or 4 months," I explain. "It's really expensive."

I have the feeling it won't matter, though, if the pharmacy cuts her a break.

"Do you want to quit?"

"Yeah."

"It's just hard," I say. My weak attempt at empathy doesn't pass through her skin.

She says she wants to change everything - the diet, the smoking, and the sugar control. If I'm a machine, she's a baseball mitt straight from the factory. Until you oil the palm and play a season of catch, the leather is 
thick and unyielding. If only she'd check her blood glucoses and cut out the soda pop...

"I've tried that," she says. No doubt she has.

I stand and take a step toward the door. "You take aspirin?" I say.

"Yeah."

Maybe if I were a better doctor, or no, a better human, I'd have more luck. For now, perhaps the little white aspirin is her best hope.

It was the love of patient stories that tipped my scales toward family medicine. Right now, however, I don't see a person with a name and personality. I see a ticking time bomb, an embolic stroke or myocardial infarction waiting to happen.

Brushing my badge against the scanner, I listen for the beep and enter the hidden quarters of the clinic. In my first job in northern Maine, I had an office to myself. In that quiet space, I dictated, meditated, and contemplated. Here in Alaska, we have what might be called an "open office." Head-high dividers cordon the several dozen employees into teams. There are doctors, medical assistants, nurses, nurse practitioners, physician assistants, clerks, case managers, care coordinators, and behavioral health clinicians. There's a trade-off: proximity facilitates collaboration, solitude favors contemplation.

After notifying the wound care nurse about my patient, I approach the physician's assistant, Stephanie, who, at the moment, seems to be everything my patient is not. A tall, confident woman with a bright smile, she has just returned from the summit of Kilimanjaro.

"Ugh," I say, as she swivels in her chair. "Everything I suggest to this patient 'doesn't work.' It's so frustrating. She's huge and she smokes and she's on like 10 medications."

Fifteen years my younger, Stephanie is neither jaded nor ignorant.

I continue to vent: "She could get off all of themher anti-hypertensives, her diabetes medicines, her cholesterol medicine-if she would just lose weight."

It's not that I'm culturally ignorant. I know the traumatic history of this land: the microbial plagues, the famine, the cultural genocide. I've spent many weeks in the villages, and convened community meetings to dialog about cancer, substance abuse, diet, and suicide. Today, however, this knowledge is lost to me, buried beneath a thick crust of frustration.

"Some people..." I say, "everything you propose, they have an answer."

Stephanie doesn't judge me. "Those patients," she says, "are depressed."

"Yeah," I say. Whether or not the patient is clinically depressed is not really the question, but sometimes a friend's advice works, not because of diagnostic accuracy, but because it slips the heart into a more productive channel of thought.

After the wound care nurse leaves the room, I start back in with my patient. "Some patients who have a hard time quitting smoking have trauma in their past," I say. "Do you have any unresolved trauma-physical or sexual?"

My inquiry is too abrupt, and probably too presumptuous, but my patient levels with me, anyway. "When I was 14 years old, I was raped by someone in the village."

Statistically speaking, one-half of my female and one-quarter of my male patients have experienced sexual trauma. "Did you get care?" I say.

"My Mom took me to get seen and we put the man behind bars."

The sexual trauma is not surprising. The imprisonment is. Few sexual trauma survivors or their families want to disturb the social fabric of the village. The perpetrator may be an important provider or leader, and the survivor may even fear that she'll be the cause of his or her suicide.

"Did you ever get counseling?"

"I went a couple times."

"Hmm."

"I started drinking after that. They sent me to rehab in Arizona."

"Uh-huh."

"How was it?"

"It was okay."

"Did it work?"

"Not really. I drank for the next decade."

"Do you think the trauma is still affecting you?" I say.

Though I learn a bit more about her life-that she smokes against the stress of living with her new boyfriend, occasionally has panic attacks, and frequently can't sleep-I leave unsatisfied. And I think she does too. She doesn't commit to quitting tobacco, dismisses the idea of a dietician with, "I've seen them before," and refuses counseling, even if the counselor is waiting in the wings.

Sometimes I leave a room with words of encouragement, something like, "You can do it, I know you can," or, simply, "Take care." It can be a bit paternalistic, I know, and today, in particular, such words would seem false. "My nurse will come in to take you to the lab," I say. We don't leave as friends, but we are polite.

At the end of the day, a surgeon knows she's changed the world. She commands the surgical field. "Scalpel," she says. She cauterizes bleeders, hands off the appendix, and closes the case. What do I command beyond a steady income?

Sometimes at dusk when I travel by foot down the dirt road overlooking the great flat valley where most 
of my patients live, I feel regret. I think that I should have spent my life creating something concrete, like bridges or movies. Maybe even now I should rekindle my dream of becoming a bigwig at the World Health Organization. As I descend from the crest line toward a grove of birch trees, I pull out my smart phone and take a sip of social media. "Chena!" I call, when a car rumbles up the slope. My golden retriever comes bounding up the road to sit by my feet until the danger is passed. I snap her picture and post it on the web.

On these days, when I'm retracing my steps back up the hill between the birch, the dog again sniffing around in the alder, my phone now zipped away in my cargo pocket, I recognize my failures. I should have explored my patient's successes, not only her deficits. I should have communed more and checked off boxes less. Cultural insight gleaned from past experience doesn't substitute for a quiet mind, a refreshed body, and a curious heart. "Tell me about how you were able to quit alcohol," I should have said. "Tell me about your hopes and dreams." Maybe that simple reaching would have opened us into each other.

But I also remind myself of the good I've done. I remember the elderly gold miner with the history of stroke who got his diabetes under control and the woman I diagnosed with primary biliary cirrhosis. I doubt any of the babies I've delivered would have died without my care. Even the new mother whose eyes dimmed with hemorrhage would likely have survived without me in specific. Someone else-any family doctor, midwife, or obstetrician-would have dug the clots out of her womb and cried, "Hemabate!" Maybe I've even made mistakes, both big and small, which have endangered human life. I know I have. But I hope that, for the most part, I have confirmed in my patients a sense of their own strength and value as human beings.

And the other thing I say to myself now as I write within a hilltop of fallen leaves is this: I am that someone else. We're all that someone else, aren't we, whether we ascend to lofty positions or dig quietly in the valley? In primary care, most of our interventions are not determinate. We can only hope to shift the odds in the patient's favor. Someday my little piece will make a difference, we say. We walk by faith, even while grounded in the scientific evidence. Maybe my moon-faced patient will knit socks for an uncle dying of lung cancer. He'll pat her hand, and on her walk home, the heavens will conspire. Blue-green ribbons, the northern lights, will snake across the sky and, stopping by the river, she'll look up. Something will shift, won't it?

She'll fly into town and check in at the front desk. Probably I won't be working the urgent care that day. She wouldn't remember me, anyway. But perhaps a moment the two of us shared will join hands with other moments life brings, and those other moments will give meaning to ours. My faith is not blind: I've seen people heal. Some other doctor will enter the room, set her laptop down on the counter, and continue the journey.

Some days we don't feel it, do we-that lively pulse that called us to medicine? We don't sense that fleshy compassion that inspired us. For whatever reason, we go home without a "story" to tell. But maybe it's true that we together, imperfect doctor and impassive patient, laid down one plank on the bridge of trust. Can I be that someone else, that faceless doctor that asked the questions and listened, if not with welling heart, at least with the integrity of honest intent? Can I be that nameless man that played his part one cold autumn day? I pray that I am.

To read or post commentaries in response to this article, see it online at http://www.annfammed.org/content/13/3/279.

Submitted October 13, 2014; submitted, revised, January 11, 2015; accepted January 23, 2015. 